\title{
Canary Wharf Crossrail station cofferdam, London, UK: design, construction and performance
}

1 Ronan Travers MSC, DIC, CEng, MIEI Senior Engineer, Ove Arup \& Partners Ltd, London, UK
2 Hoe-Chian Yeow BSc, PhD, CEng, MICE Technical Director, Flint \& Neill, UK; formerly Arup

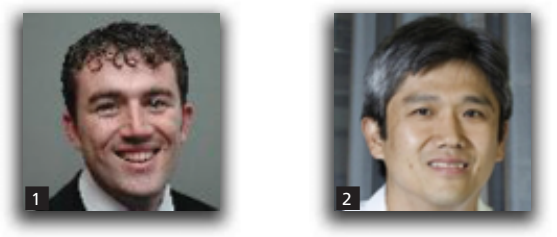

The construction of the first Crossrail station at Canary Wharf in London, UK reached a significant milestone in March 2012 when the station box was formally handed over to Crossrail for the preparation of the tunnel eyes to receive and re-launch the tunnel-boring machine. The station box is constructed in the North Dock at Canary Wharf in around $9 \mathrm{~m}$ of dock water. Excavation of the $265 \mathrm{~m}$ long, 25-30 m wide and $18 \mathrm{~m}$ deep station box was completed in about 12 months. This paper provides useful guidance for practising engineers on the design and construction of cofferdams' retaining walls in a dock environment. It describes the performance of the retaining structures constructed using the innovative Japanese Giken tubular pile system. Some details are also included of the site-wide dewatering undertaken to lower the groundwater in the Chalk and control it, allowing excavation into the Upnor Formation and Thanet Sand. The effects of unexploded ordnance probing on the performance of the retaining wall are described. Together with details of the laboratory tests undertaken to inform the ship impact berm design and the monitoring system used to verify the retaining wall design and comparison of the predicted and measured wall movements during excavation.

\section{Introduction}

The Canary Wharf Crossrail station (CWCS) in east London, UK is located within the historical West India Docks, in the heart of one of London's financial districts, and forms part of the third railway link into the city centre. The station structure is typically $260 \mathrm{~m}$ long, between 25 and $30 \mathrm{~m}$ wide and constructed within a cofferdam. It has two storeys both above and below dock bed level. The formation level of the station box is approximately $18 \mathrm{~m}$ below the dock bed level and the dock is $9 \mathrm{~m}$ deep.

The cofferdam was formed of a tied-back retaining wall on three sides and utilised the basement structures to the south to provide water cut-off. The retaining wall was a composite steel/concrete piled wall formed in part using the Japanese Giken silent piling system. This was the first such project in the UK using the Giken technique over water on this scale. To reduce the effects of construction on adjacent structures, top-down construction was used.

This paper discusses in detail the design and construction of the tied-back retaining wall system that formed the northern part of the cofferdam. Predicted movements are compared with field measurements to assess its performance.

\section{Ground and groundwater conditions}

\subsection{Ground conditions}

The typical geological sequence on the site is sand and gravels of the River Terrace Deposits and Harwich Formation, followed by Lambeth Group, Thanet Sand and Chalk. The stratigraphy of the site determined from the borehole information is summarised in Table 1. An east-west geological section (1) is shown graphically in Figure 1. The plan location of the boreholes and section line is presented in Figure 2. The moderately conservative geotechnical design parameters (as defined by Gaba et al. (2003)) are presented in Table 1 .

A detailed ground investigation confirmed that a minor geological fault in the N-NW to S-SE direction is located to the east of the station box. This is shown in plan later, in Figure 6, where its effects on the local groundwater regime during dewatering can be seen.

\subsection{Hydrogeology}

The hydrogeology of Canary Wharf as part of the London Basin is well known. It is formed by two separate aquifers known commonly as the Upper and Lower aquifers. The surface water bodies of the existing dock system are linked to the River Thames. These overlie the sands and gravels of the 


\begin{tabular}{|c|c|c|c|c|c|c|c|c|}
\hline Strata & $\gamma: \mathrm{kN} / \mathrm{m}^{3}$ & $\begin{array}{l}\phi^{\prime} \text { peak: } \\
\text { degrees }\end{array}$ & $c_{u}: k P a$ & $\begin{array}{c}\text { Standard } \\
\text { penetration } \\
\text { test N-value }\end{array}$ & $\begin{array}{l}E_{\text {uh }}: \text { MPa } \\
\text { (see table } \\
\text { footnote) }\end{array}$ & $\begin{array}{c}E_{v}^{\prime}: \text { MPa } \\
\text { (see table } \\
\text { footnote) }\end{array}$ & $\begin{array}{l}E_{h}^{\prime}: \text { MPa } \\
\text { (see table } \\
\text { footnote) }\end{array}$ & $K_{0}$ \\
\hline Superficial deposits & 17 & 25 & - & 5 & & 5 & - & 0.58 \\
\hline Dock sediment (cohesive) & 13 & 20 & 5 & - & & 0.9 & - & 0.65 \\
\hline River Terrace deposits & 20 & 38 & - & 20 & & 25 & 50 & 0.38 \\
\hline Harwich Formation & 20 & $28-35$ & - & $15-50$ & & 30-95 & - & $1 \cdot 0$ \\
\hline Lambeth Group - clays & 20 & $21 \cdot 5-29$ & $17 z+70$ & $21 \cdot 5-29$ & $17 z+70$ & $4 \cdot 25 z+17 \cdot 5$ & $12 \cdot 8 z+52 \cdot 5$ & $1 \cdot 4$ \\
\hline Lambeth Group - sands & 20 & 33 & - & 60 & & 120 & - & $1 \cdot 1$ \\
\hline Thanet Sand & 19 & 36 & & 175 & & 260 & & $1 \cdot 1$ \\
\hline Chalk & 19 & 34 & & 125 & & $625-5000$ & & $1 \cdot 0$ \\
\hline
\end{tabular}

Note: $\gamma$ is undrained weight; $\phi^{\prime}$ is peak angle of shearing resistance; $c_{u}$ is undrained shear strength; $c^{\prime}$ is assumed to be zero; $K_{0}=1-\sin \phi^{\prime}$ (for normally consolidated deposits); $K_{0}$ in Lambeth Group is taken from Ciria C580 (Gaba et al., 2003); $K_{0}$ in Thanet Sand is from Newman et al. (1991) and the Arup database; $z$ is defined as depth below top of stratum; $E_{\mathrm{h}}$ is associated with strains between 0.01 and $0.1 \%$ and $E_{\mathrm{v}}$ between strains of 0.3 and $0.5 \%$.

Table 1. Moderately conservative geotechnical design parameters

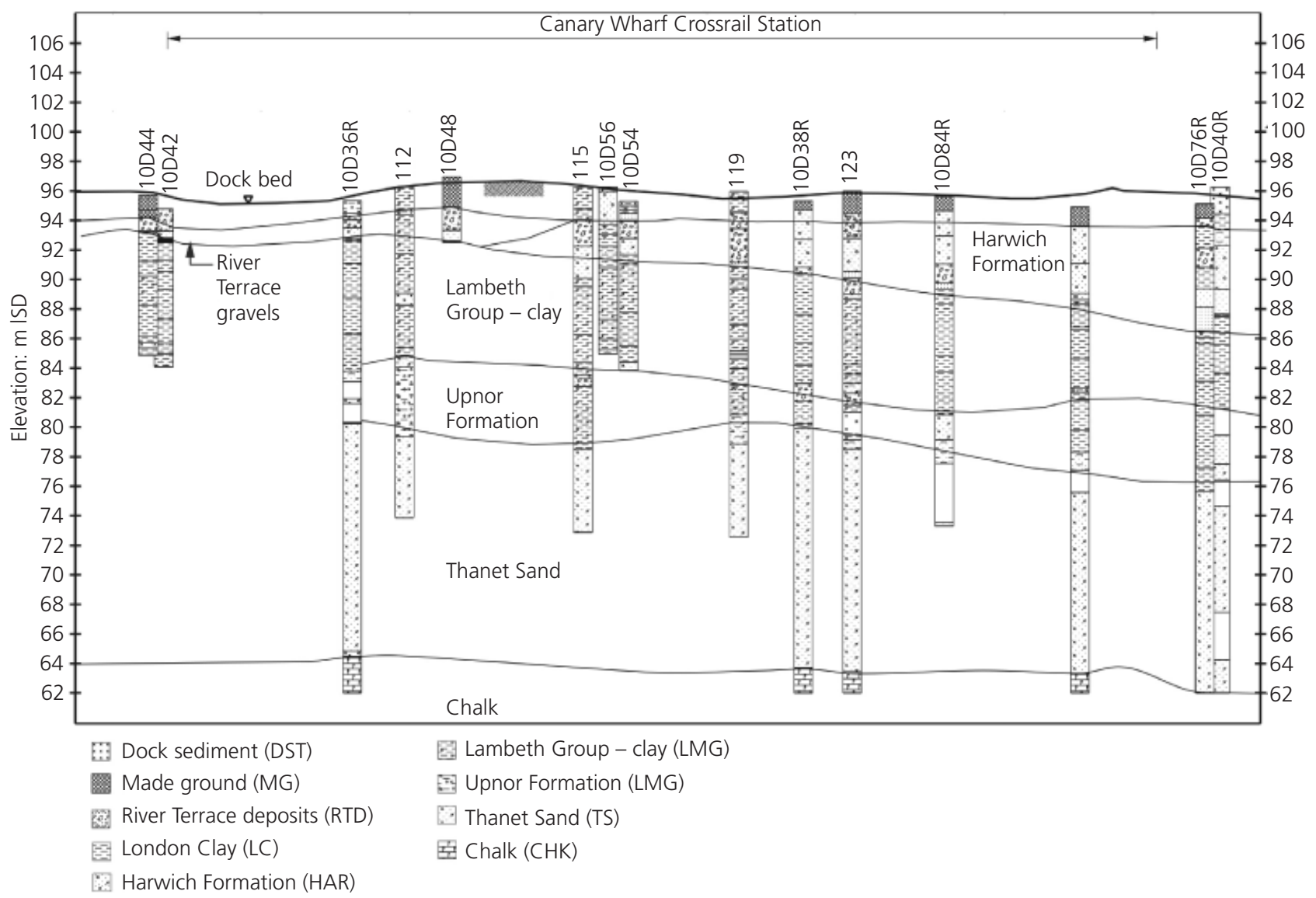

Figure 1. East-west geological cross-section (section (1))

River Terrace Deposits and Harwich Formation, all of which form the Upper aquifer. Separating the two aquifers is the aquiclude, formed of low-permeability Lambeth Group clays. The Lower aquifer is also known as the 'Chalk-basal sands aquifer' and comprises the Lambeth Group sands, Thanet Formation and the Chalk group.

Historically the Lower aquifer was artesian to sub-artesian in 


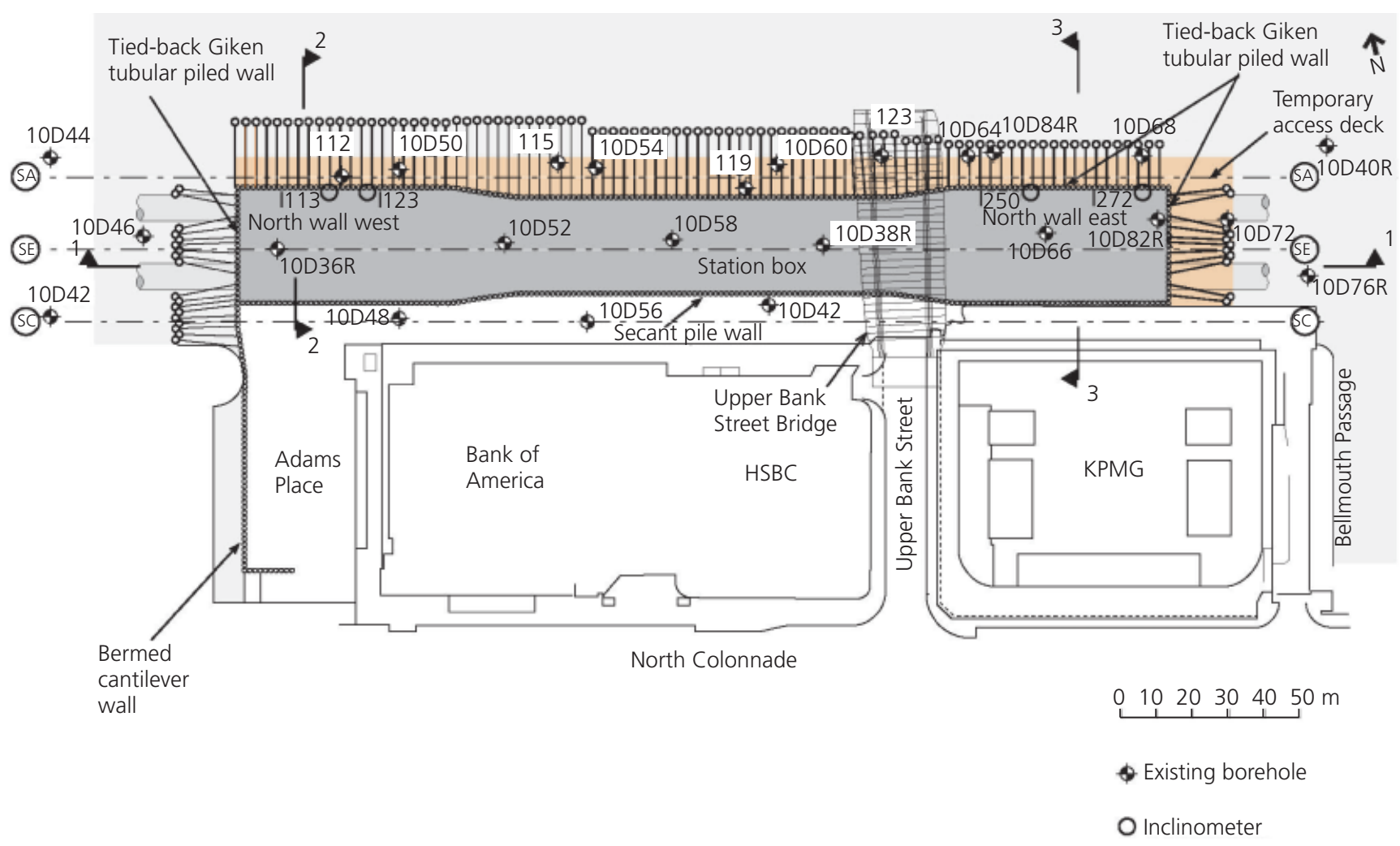

Figure 2. Plan of tied-back cofferdam

nature. However, past groundwater abstraction has resulted in the classic under-drained profile that is seen throughout London today. The groundwater profile is presented in Yeow et al. (2012). The decline in abstraction rates since the 1960s has resulted in a rise in the water level, which has been well documented since Simpson et al. (1989). The station box design accounted for uplift forces arising from this possible return of the groundwater to its natural artesian level.

A long-term design groundwater level of $101 \mathrm{~m}$ ATD (above tunnel datum) was used, which is consistent with the Crossrail project-wide requirement. In addition, two extreme water levels design cases were also examined: $(a)$ dock gate failure and $(b)$ dock flood event over the 120-year design life of the structure.

A geotechnical baseline report was used to clearly define the commercial risk associated with both the ground and groundwater conditions.

\section{Design}

\subsection{Introduction}

The early Crossrail scheme was changed significantly, drawing on both the client's (Canary Wharf Contractors Ltd) and the designer's extensive experience of constructing in the Canary Wharf dock system. The design development is explained in detail in Yeow et al. (2012).
The key client requirements incorporated into the station scheme are as follows.

(a) Minimise noise during the piling operations.

(b) Reduce the volume of excavated material to be disposed offsite.

(c) Maintain the dock for ship navigation and consider an allowance for ship impact loads on the station structure.

(d) Minimise the impact of ground movement on adjacent structures.

(e) Design the station for a long-term dock gate failure condition.

( $f$ ) Remove the need for internal temporary propping of the cofferdam.

( $g$ ) Reduce the loss of flood storage potential due to the additional retail development above dock level.

Early contractor (Expanded Ltd) involvement at tender design resulted in a tied-back retaining wall system being developed. The tied-back cofferdam was formed on three sides of the station and utilised the existing basements of the buildings to the south to provide partial water cut-off.

\subsection{Cofferdam}

The east, north and west retaining walls were formed using 310 interlocking tubular steel piles installed over water using the Giken silent piling technique. The Giken system is described in 
detail in Yeow et al. (2012); it uses a combination of augering and hydraulic push-in force to advance the piles. The geometries of the tubular steel piles were $1219 \mathrm{~mm}$ external diameter, typically $14 \mathrm{~mm}$ wall thickness and between 18.1 and $18.5 \mathrm{~m}$ long. The piles were interlocked, using grouted Giken's P-P clutches, to prevent water ingress into the cofferdam. Conventional bored piles were then constructed through the toe of the tubular piles to form a composite wall, known as the Giken wall.

This retaining wall was tied back to single anchor piles, located at $2.92 \mathrm{~m}$ plan centres. The geometries of the steel anchor piles were $1219 \mathrm{~mm}$ external diameter, typically $14 \mathrm{~mm}$ wall thickness and $18.5 \mathrm{~m}$ long. They were installed using conventional piling equipment over water. A reinforced concrete pile was formed, using the same techniques as the Giken wall, through the base of this steel tube to a toe level between 76 and $77.5 \mathrm{~m}$ ATD (above datum).

Tie rods were installed between the retaining wall and each anchor pile. The vertical angle of the tie rod varied (25 to 40 degrees) to accommodate the 'dog-bone' shape of the station and was formed in three parts. The initial section $(200 \times 40 \mathrm{~mm}$ thick batten plates spaced $170 \mathrm{~mm}$ apart) was fixed vertically to the steel anchor pile (prior to installation) to a knuckle pin joint, allowing the section to rotate. The mid-section was then lowered by crane to facilitate a bolted connection above water. The combined section was then lowered further to a position just below the capping beam. The tie was completed using a Daver rod (M100 grade 520) threaded both ends and inserted through a preformed $244 \mathrm{~mm}$ steel tube in the capping beam. A temporary deck was used as a construction platform. The deck was designed with a sliding joint on the anchor pile to prevent overstressing of the anchor tie. This completed the tied-back retaining wall. Section (2) through the north wall west is shown in plan in Figure 2 and in elevation in Figure 3. A section (3) through the station box is presented in Figure 4. The current paper focuses on the performance of the north cofferdam wall.

\subsection{Construction sequence}

The first activity on site was dewatering of the Lower aquifer prior to pile construction. Interlocking steel tubular piles were then installed over water using the Giken system. This was followed by conventional bored piling from barges through the toe of the steel tubular piles. A tieback back-propping system completed the cofferdam and gave the advantage of an obstruction-free site.

The tied-back wall was prestressed using hydraulic jacks to an equivalent horizontal force of $100 \mathrm{kN} / \mathrm{m}$. The actual force in the tie varied depending on the tie spacing and tie anchor angle in both plan and elevation. The load was built up in successive cycles of jacking until the required design load was achieved. There was poor agreement between the tie force measured by the hydraulic jack pressure gauge and the load cell, resulting in lower force being jacked into the tie during initial load cycles. This was resolved by further rounds of jacking by measuring all loads using load cells.

Once the prestressing operation was completed around $100000 \mathrm{~m}^{3}$ of water was pumped over a $13-\mathrm{d}$ period to drain the dock. This dock draining operation was a two-stage process where a pause in pumping allowed second-stage prestressing of the anchor ties at both end walls (east and west). This pause also allowed the designer the opportunity to confirm the performance of the retaining structures by comparing it against predicted behaviour.

Removal of any remaining dock sediment provided a dry working environment for the unexploded ordnance (UXO) probing and piling. The south retaining wall was formed of a hard-firm bored secant pile wall (1180 $\mathrm{mm}$ diameter at 875 centres).

In addition, 71 no. $1200 \mathrm{~mm}$ diameter tension piles and 30 no. $2100 \mathrm{~mm}$ plunge column piles were installed along the station centre line. The plunge column piles were constructed to provide short-term support to the top-down construction. Together with the tension piles, installed to a level beneath the base of the station box, these provided the additional resistance to long-term uplift forces from rising groundwater levels.

The use of top-down construction methods minimised ground movements to neighbouring structures and the construction of ship impact islands (underwater berms) at the station ends also had the added benefit of reducing the volume of excavated material that was disposed offsite.

The general construction sequence of the north wall is outlined in Table 2.

\subsection{Wall design}

The design of the retaining wall for lateral stability was undertaken in accordance with Ciria C580 (Gaba et al., 2003). The cofferdam was modelled using the two-dimensional finite-element Plaxis program (version 9.0). The model assumes plane strain conditions and all the soils were modelled using a linear elastic, perfectly plastic Mohr-Coulomb soil model. Lambeth Group clays were modelled as undrained during the construction phase of the station box. This assumption was based on observed wall movements in retaining structures in the same ground conditions in Canary Wharf and the surrounding areas.

Consideration has been given to modelling the stress history of the ground at the site to correctly assess the in situ horizontal stresses. The initial conditions were based on an assumed site history and on measurements of the coefficient of earth pressure at rest, $K_{0}$, obtained by Newman et al. (1991) at Port East to the north west of the West India Dock.

The use of finite-element analysis allowed the modelling of asymmetric loading, or 'sway', from the tied-back cofferdam 


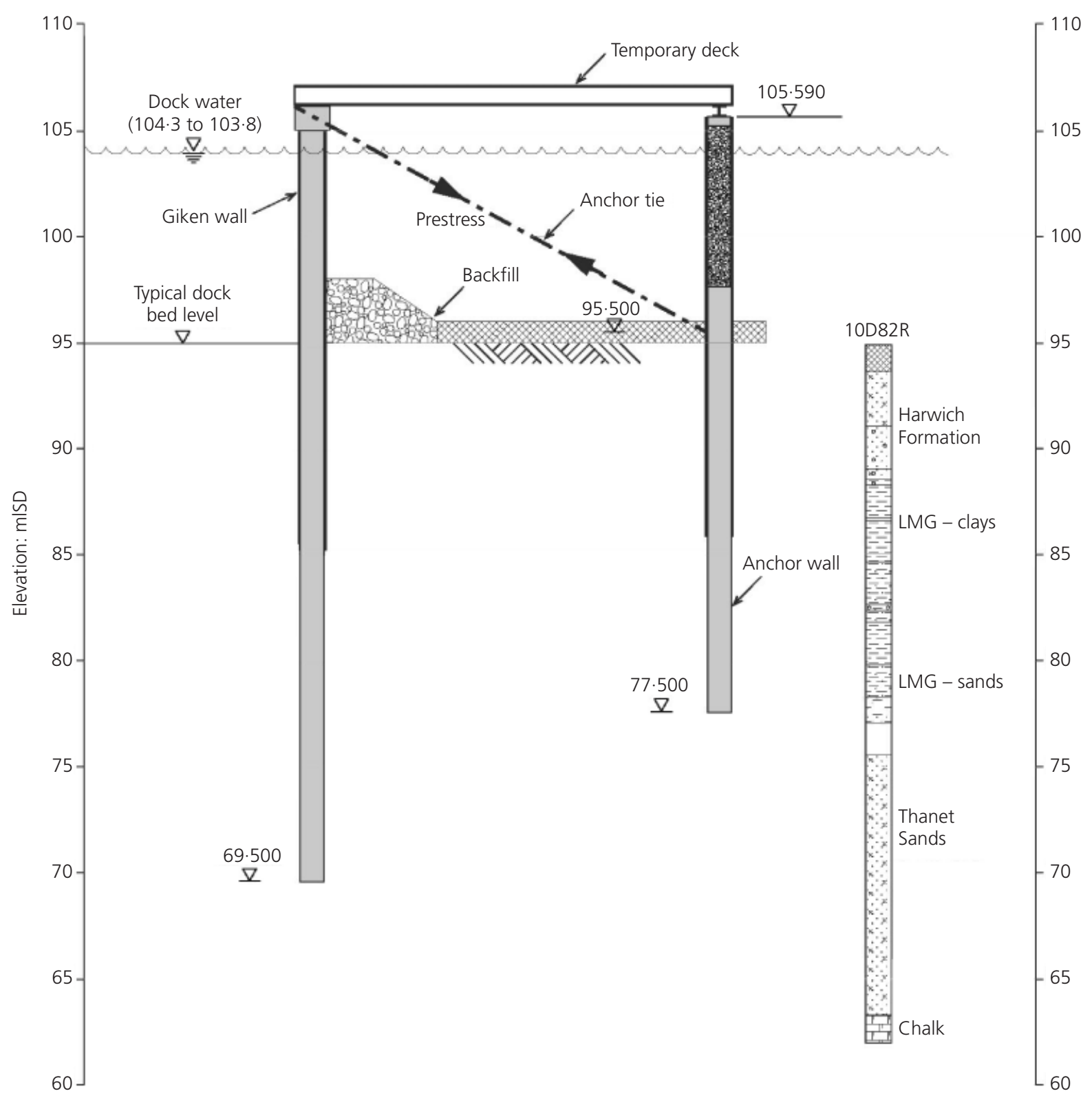

Figure 3. Section (2) through tied-back retaining wall

towards the existing buildings to the south. This was due to the out-of-balance force caused by retaining dock water acting on only one side (north cofferdam) of the station during construction, see Figure 4. This model also included the adjacent buildings and structures surrounding the station as part of the existing buildings/structures impact assessment.

\section{Construction}

\subsection{Site dewatering}

The benefits of lowering the groundwater in the Lower aquifer to allow time and cost savings in the construction of bored piles has been used successfully on the Canary Wharf estate since the construction of the Jubilee Line extension (JLE) in the mid- 1990s. This approach allows increased pile production by reducing and in some cases omitting the need for drilling support fluid.

Dewatering commenced in August 2008, and up to 14 dewatering wells were utilised to extract water from the Upper Chalk, thus under-draining the Thanet Sand above. Figure 5 shows that the rate of abstraction peaked at over $175 \mathrm{l} / \mathrm{s}$ during the initial dewatering stage, reducing to a constant rate of around $130 \mathrm{l} / \mathrm{s}$ when the water level in the sands reached their lowest level.

The original design was to lower the water level to the top of the chalk layer ( $\sim 63 \mathrm{~m}$ ATD). Figure 5 also shows that water levels dropped to an increasingly slower rate after about 12 months, 


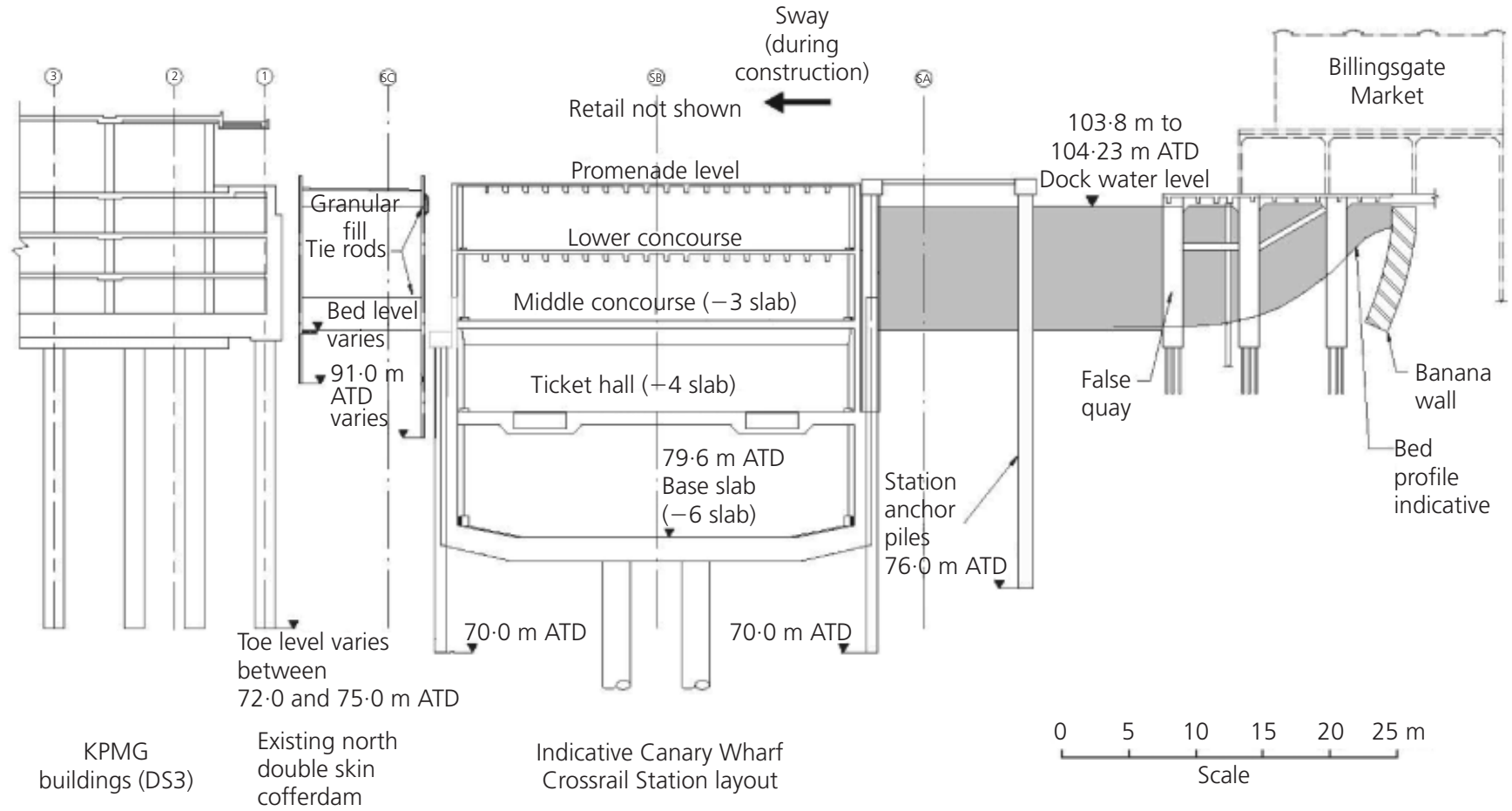

Figure 4. Section (3) through east end of station box

\section{Stage Activity}

$1 \quad$ Dewatering lower aquifer

2 Dock silt removal

3 Prestressing anchor ties

$4 \quad$ Drain dock

5 Probe for UXO, install south secant piled wall, piling works

6 Excavate to $93.1 \mathrm{~m}$ ATD, install -3 slab

7 Excavate to $87.7 \mathrm{~m} \mathrm{ATD}$, install -4 slab

8 Excavate to $77.6 \mathrm{~m}$ ATD, install base slab (-6 level)

9 Construct south wall and -2 and -1 slab

10 Destress anchor ties

11 Arrival of tunnel-boring machine

Table 2. Key construction activities

with the water in the Lower aquifer maintaining its level at around $3-5 \mathrm{~m}$ above the chalk. Piezometer and well locations are shown in plan in Figure 6, where groundwater level contours at the end of dock draining are superimposed on an outline of the station box. It was possible that suction (air pressure below atmospheric) developed in the Thanet Sand, preventing further drawdown of the lower aquifer to the top of the chalk. A new target level of $1 \mathrm{~m}$ below pile toe was set. In parallel, a smallscale trial of injecting air to relieve the suction in the Thanet Sand was undertaken, but proved inefficient at reducing the piezometric pressure. In the event, full-scale implementation of air injection was not required as the new target level was reached ( $\sim 67 \mathrm{~m}$ ATD), see Figure 5 .

\subsection{Giken piling}

Two Giken rigs installed steel tubular interlocking piles, ranging in length between $18.1 \mathrm{~m}$ and $18.5 \mathrm{~m}$, using a combination of augering and hydraulic push-in force to advance the piles. All the tubular piles were successfully installed to the required depths.

An adequate hydraulic seal into the Lambeth Group clay was fundamental for the water cut-off to work and as a result the last $0.5 \mathrm{~m}$ of the steel pile was pushed in without augering. The average production rate of the Giken piling rig was three tubular piles per day up to a maximum of four, assuming no head room or other restrictions to working conditions.

The maximum observed vertical push-in force was between 1500 and $1800 \mathrm{kN}$; up to $9 \mathrm{kN} \mathrm{m}$ of auger torque was also noted. The construction tolerances achieved during the works are presented in Table 3 and showed the overall tight control on site.

\subsection{Bored piling}

Bored piling was undertaken from the dock bed and toe level that varied between $69.5 \mathrm{~m}$ ATD along the north wall west to $70 \mathrm{~m}$ ATD along the north wall east. Typical 'splash and dash' drilling techniques involved boring the pile to the specified toe level in the dry (no support fluid) then introducing clean drilling fluid to 
Geotechnical Engineering Volume 167 Issue GE2
Canary Wharf Crossrail station cofferdam, London, UK: design, construction and performance

Travers and Yeow

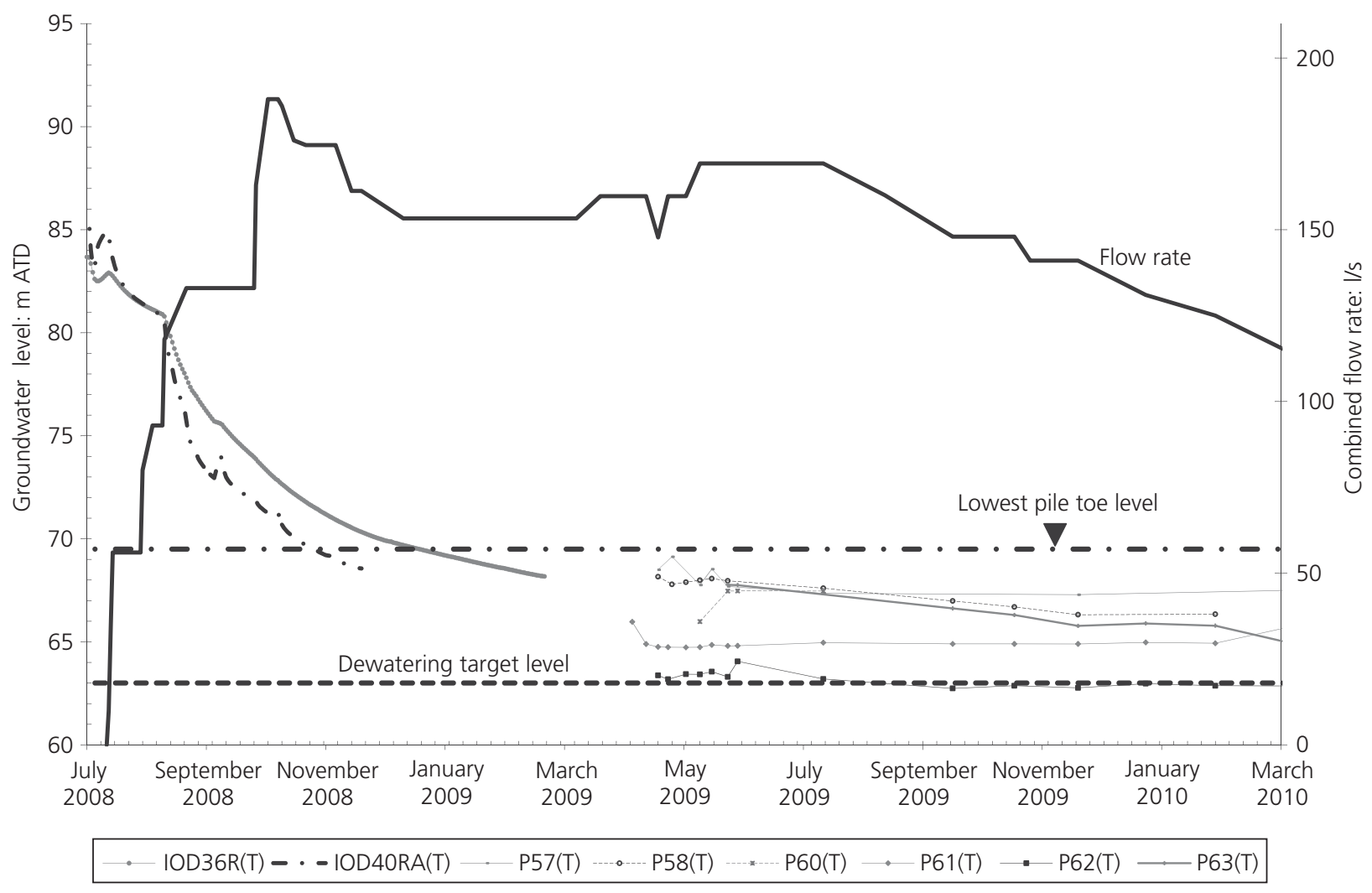

Figure 5. Pump rates against draw-down contours

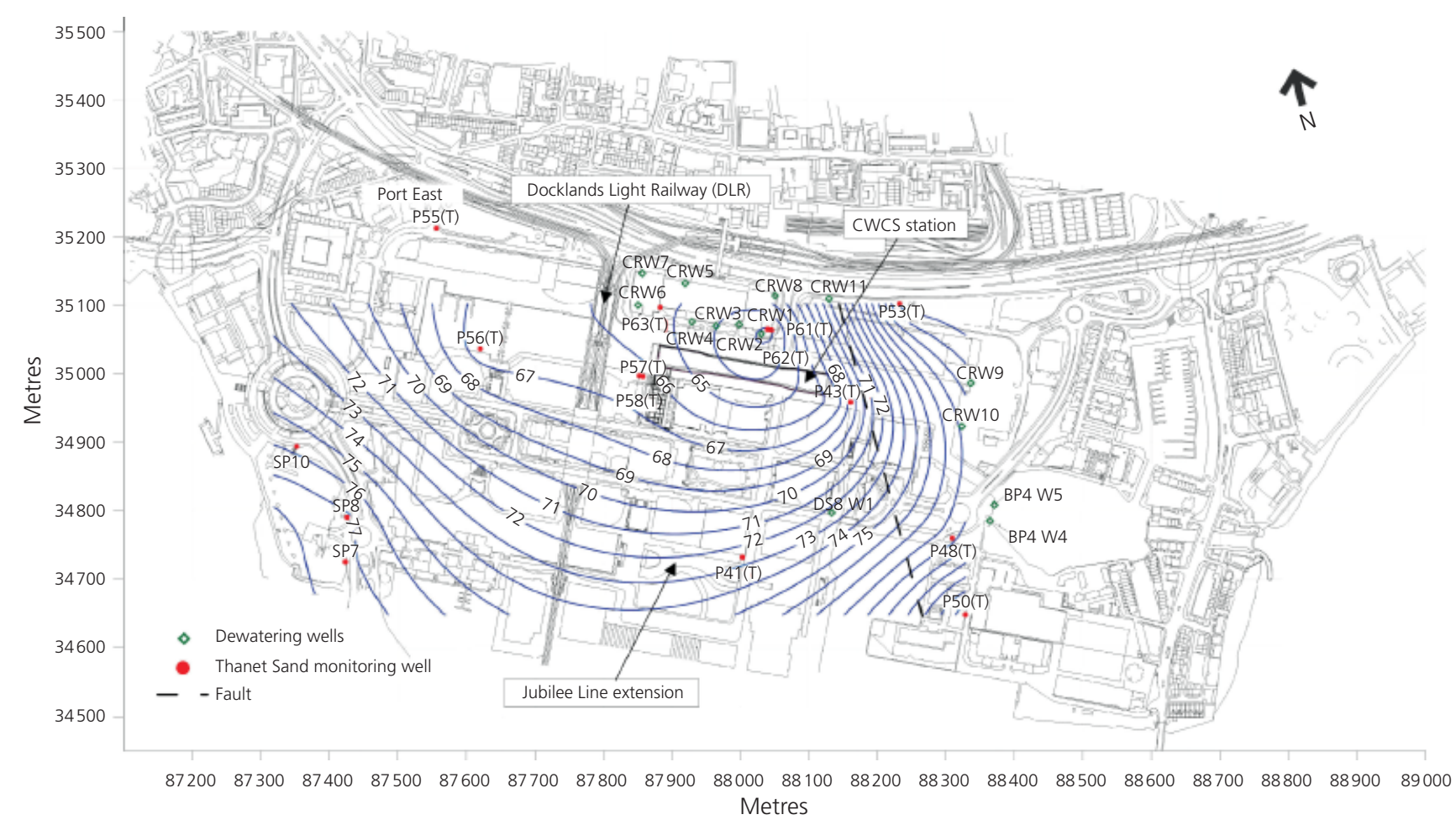

Figure 6. Plan of post-dewatering groundwater contours within the lower aquifer (Thanet Sand and Upper Chalk) 
Specified \% within Overall 95\%

tolerance specified tolerance

tolerance achieved

\begin{tabular}{lccc}
\hline Plan position & $\pm 25 \mathrm{~mm}$ & 93.5 & $\pm 26 \mathrm{~mm}$ \\
Level & $\pm 20 \mathrm{~mm}$ & 99.5 & $\pm 10 \mathrm{~mm}$ \\
Verticality (over 7 m) & $1: 125$ & 97.5 & $1: 150$
\end{tabular}

Table 3. As-built data for tubular pile installation

support the bore until completion of the concreting operations. This process minimised or eliminated the need to de-sand the bentonite prior to concreting, hence saving valuable construction time.

Some of the piles were bored and cast in the 'dry', without using support fluid, to increase production, but with limited success. To prevent collapse of the side walls of these piles, toe levels were founded above the groundwater level. Limits to the amount of debris accumulation during construction of the tension piles were adopted following site trials. Base cleaning and base hardness measurements were performed on compression piles.

To provide temporary support of the slabs during top-down construction, plunge columns (verticality 1 in 200) were cast into the $2.1 \mathrm{~m}$ diameter piles. The piles were founded in the Upper Chalk at $56 \mathrm{~m}$ ATD, below the water table, and thus required bentonite fluid to support the bore. A construction time of $12 \mathrm{~h}$ was specified for these piles. To prevent delay in construction, rules based on historical load tests were developed that allowed the contractor to extend the pile length if the construction time exceeded the specified $12 \mathrm{~h}$. The $1200 \mathrm{~mm}$ tension piles were also founded in the Chalk at $57 \mathrm{~m}$ ATD under bentonite.

\subsection{Probing for UXO}

Unexploded ordnance probing using specialist equipment was performed in advance of the piling works to mitigate the risk of World War II UXO being encountered during construction. Probing was undertaken using an uncased, high-pressure (up to 11 bar), rotary, percussive, air-flush drilling system. This system of flush control resulted in large increases in pore pressure measured using vibrating wire piezometers located at the toe of the tubular piles. This large excess pore-water pressure resulted in an unexpected lateral movement of the north wall east cofferdam wall. This was between 2 and $7 \mathrm{~mm}$ in magnitude and is shown later, in Figure 11.

The exact cause of this wall movement (attributed to UXO probing) was not clear, but two possible hypotheses to explain it are given below.

(a) The high air pressure acting on the clay is similar to cavity expansion. An increase in total stress $(\Delta u=B \Delta \sigma)$ caused a corresponding measured (by piezometers) increase in pore pressure. Figure 7(a) shows a possible stress path of the clay under extension. The increase in lateral stress moves the soil on to the passive failure line, resulting in additional lateral movement of the wall. However, usually if soil fails in extension under large lateral load but maintaining a constant vertical load, a drop in pore water is seen. The increase in pore water could be more localised in granular bands.

(b) The high air pressure during drilling either causes the clay to

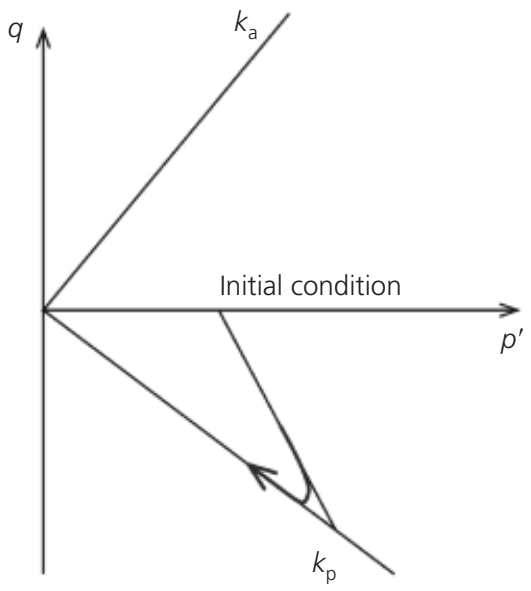

(a)

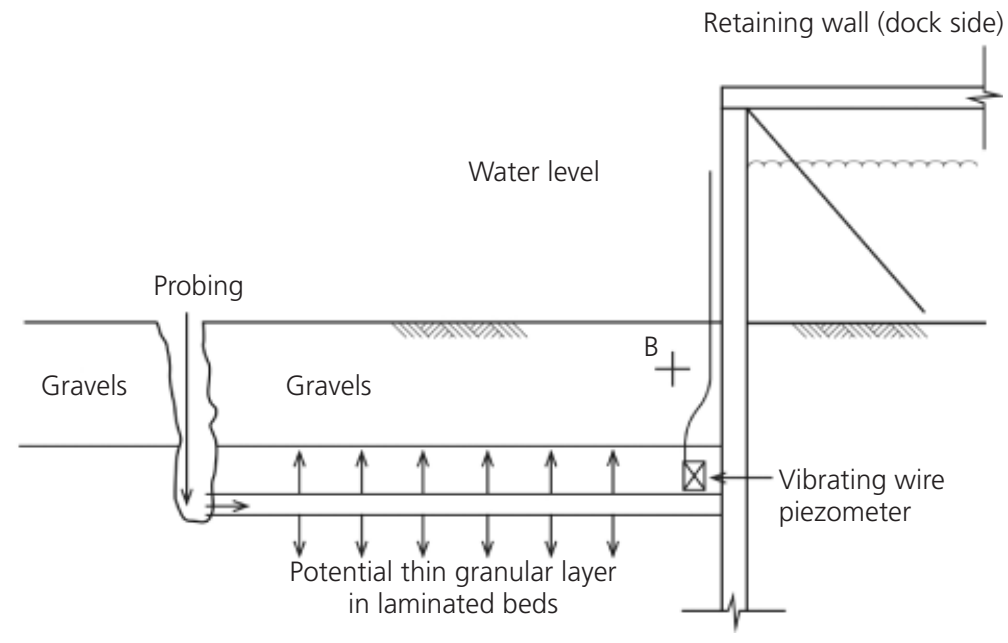

(b)

$q$, deviator stress; $p^{\prime}$, mean normal effective stress; $k_{a}, k_{\mathrm{p}}$ coefficients of earth pressure;

$B$, pore pressure coefficient; $u$, pore water pressure; $\sigma$, total stress

Figure 7. Possible mechanism due to UXO probing: (a) $\Delta u=B \Delta \sigma$

effect; (b) clay fracture 
fracture or permeates through a sand layer. Figure 7(b) shows the possible mechanism. The high air pressure within this fracture is greater than the vertical stress acting downwards from the soil above, thus causing loss of passive resistance because shearing resistance along the fractured plane is significantly reduced. This causes the soil to move as a passive wedge, allowing the wall to move with it.

\subsection{Underwater berm construction}

Two large underwater berms (islands) were located at the ends of the station as part of the ship impact mitigation strategy, see Figure 8.

To reduce the volume of excavated material from the station box being disposed in landfill, this excavated soil was instead used to construct these ship impact berms. Early laboratory model trials were undertaken on the suitability of site-won Lambeth Group sand and Thanet Sand to be placed in water as the fill material. Testing was performed in a glass tank of dimensions $1.2 \times$ $0.3 \times 0.4 \mathrm{~m}$. Water was maintained at a constant level of $0.08 \mathrm{~m}$ below the top of tank, Figure 9 .

Two methods of underwater fill placement were investigated: namely, the bottom placed method where the fill was lowered to the dock bed using the bucket of a long-reach excavator (or similar) before placement, or the 'rained' in place method, where the fill was dumped near the surface of the water. The bottom placed method demonstrated an angle of repose between 28 and $29^{\circ}$. In comparison, the surface placed method was shown to have a lower angle of repose, in the range of $16-21^{\circ}$. This method suffered from soft spots, layering and segregation of fines material. The method had clear production advantages, but was

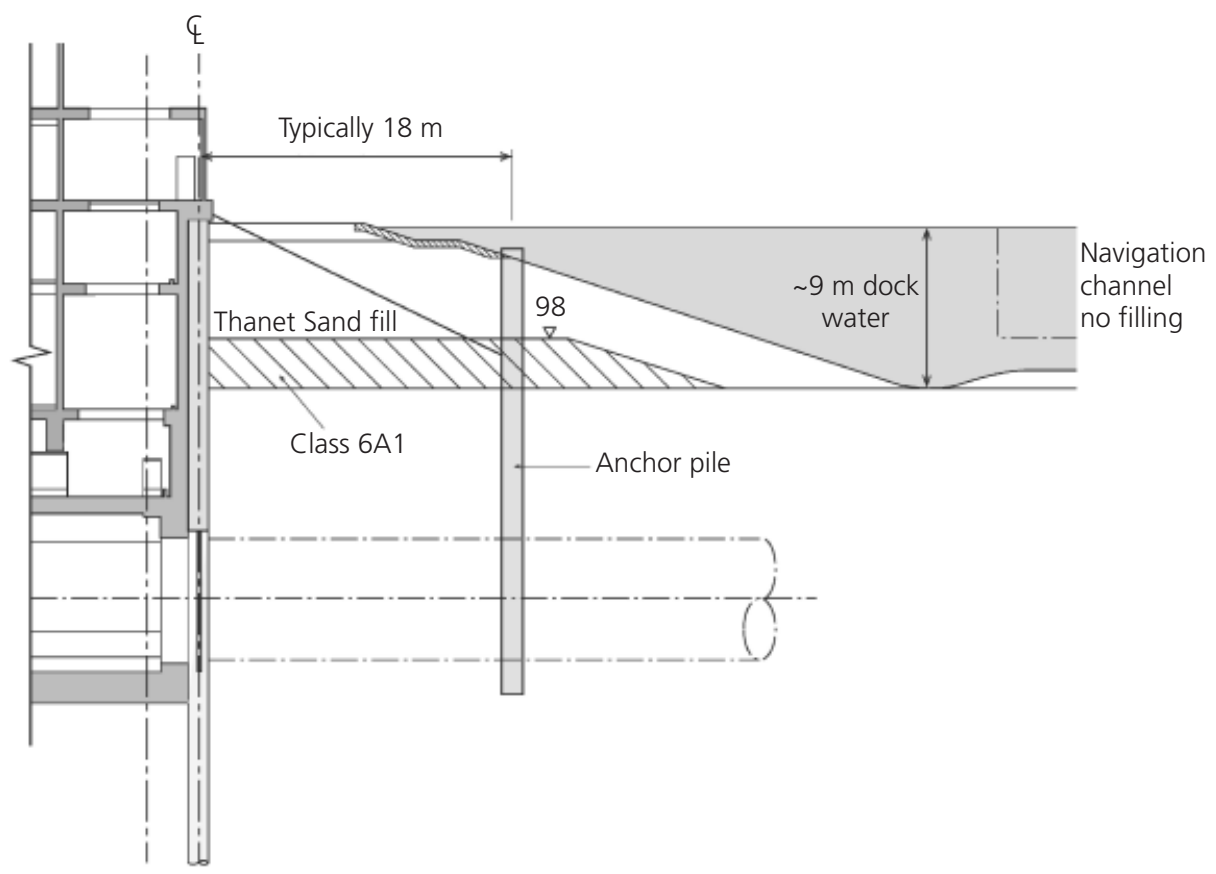

Figure 8. Ship impact island (east head wall)

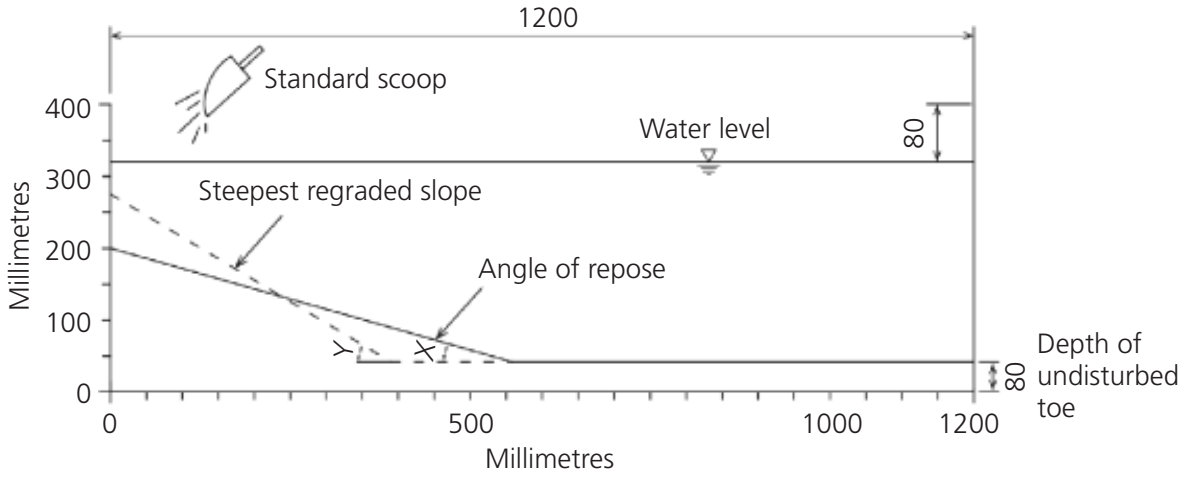

Figure 9. Model tank test (where $X$ is angle of repose) 
found to be adequate only with the use of a bottom gravel layer (classed as a 6A fill, as per the Specification of Highway Works (Highways Agency, 2000)) and follow on re-grading of the slope. The test concluded that only Thanet Sand was suitable as the fill material for the ship impact berm.

To ensure the stability of this berm, a key design requirement was the removal of the soft dock sediment layer prior to placement of the fill. During construction it was not possible to remove all of the soft sediment when dredging using a bargemounted 'backhoe' excavator. A change to airlifting was found to be more effective at removing this layer to a tolerable thickness.

\section{Field performance}

\subsection{Monitoring}

A detailed instrumentation and monitoring system was installed to monitor the performance of the retaining structure and to confirm the design. This allowed back analysis of the east and west cofferdam end (head) walls and the implementation of the observational method, which led to the omission of the temporary props from the constructions sequence. This is explained in detail by Yeow et al. (2012).

The performance of the retaining wall during dock draining and excavation was monitored using inclinometers, prisms, load cells and piezometers. The complete tie-back wall system had an inclinometer in both the Giken and anchor pile, and a load cell to monitor the force in the tie. This allowed a better understanding of the mode of deformation. Vibrating wire piezometers were installed in front of the Giken wall to allow pore-water pressure measurements to demonstrate the water tightness of the tied-back cofferdam during dock draining. Selected inclinometers on both the north wall east and west are presented in plan in Figure 2.

Steel tubes were fixed to the reinforcement cage over the full length of the retaining wall pile. Plastic inclinometer casings were grouted in place within these steel tubes after construction of the pile. The absolute position of the inclinometer was measured using optical prisms fixed to the capping beam and linked to an automated total station system.

The monitoring system used a traffic light approach for trigger values for different stages of the excavation. Red triggers were estimated wall deflections of the retaining wall system from serviceability limit state design analysis using moderately conservative design parameters (Table 1), whereas amber triggers were estimated using most probable soil parameters. In the event that these triggers were reached a set of pre-agreed actions or measures were to be implemented. This is particularly important for a water-retaining structure.

The predicted wall deflections $(\delta)$ shown in Figure 10 were originally based on $75 \%$ of the red trigger. This was corrected to $80 \%$ during the works to avoid unnecessary trigger alerts and this is the value that was used as the amber trigger, presented in Figure 10 .

1. $\delta_{\text {amber }}=80 \% \delta_{\text {red stage }}$

\subsection{North wall movements: predicted as opposed to measured}

Comparisons of the measured and predicted lateral movement of the north wall are shown for four key construction stages (prestressing, dock draining, excavate to level -3 and excavate to level -6) in Figure 10. The general construction sequence is detailed in Table 2. Two sections contrasting the variation in geology across the station are compared here and are referred to as the north wall west and north wall east. They are shown in plan on Figure 2, along with the location of the relevant inclinometers.

\subsection{Prestressing}

The first key construction stage was prestressing of the tied-back retaining wall. This introduces bi-directional movement into the Giken wall, which results initially in the wall moving away from the excavation, that is northwards (Figure 10(a)). This was followed by dock draining, which causes the wall to move towards the excavation, that is southwards. Measured movement during prestressing indicated a much stiffer response from the Giken wall, resulting in a revision to the trigger values. Typically the subsequent calculated incremental movements were added to the actual measured prestressing stage to produce new trigger values.

\section{2. $\delta_{\text {new trigger }}=\delta_{\text {previous stage }}+\Delta \delta_{\text {plaxis }}$}

Checks were undertaken on the compatibility of the new curves with the structural capacity of the Giken wall.

\subsection{Dock draining}

Inclinometer measurements were taken directly during and after draining of the dock. Both ends of the north wall had moved up to $10 \mathrm{~mm}$ when the dock was completely drained. Following completion of the soft sediment removal, piling activities from the drained dock bed continued for around 4 months. Over this period, ongoing movement was observed. The magnitude of this movement over time for the north wall east has been plotted in Figure 11, together with the construction activities over the same duration. Piezometric measurements taken from vibrating wire piezometers inside the excavation are also shown. At this stage of the work maximum lateral deflection of the station wall piles occured around dock bed level between 94 and 96 m ATD.

In the retaining wall design the Lambeth Group clay was assumed to behave as an undrained soil. However, over the 4 months that the dock was drained a proportion of the recorded movement was probably due to the partial consolidation of this clay. 
Geotechnical Engineering Volume 167 Issue GE2
Canary Wharf Crossrail station cofferdam, London, UK: design, construction and performance

Travers and Yeow
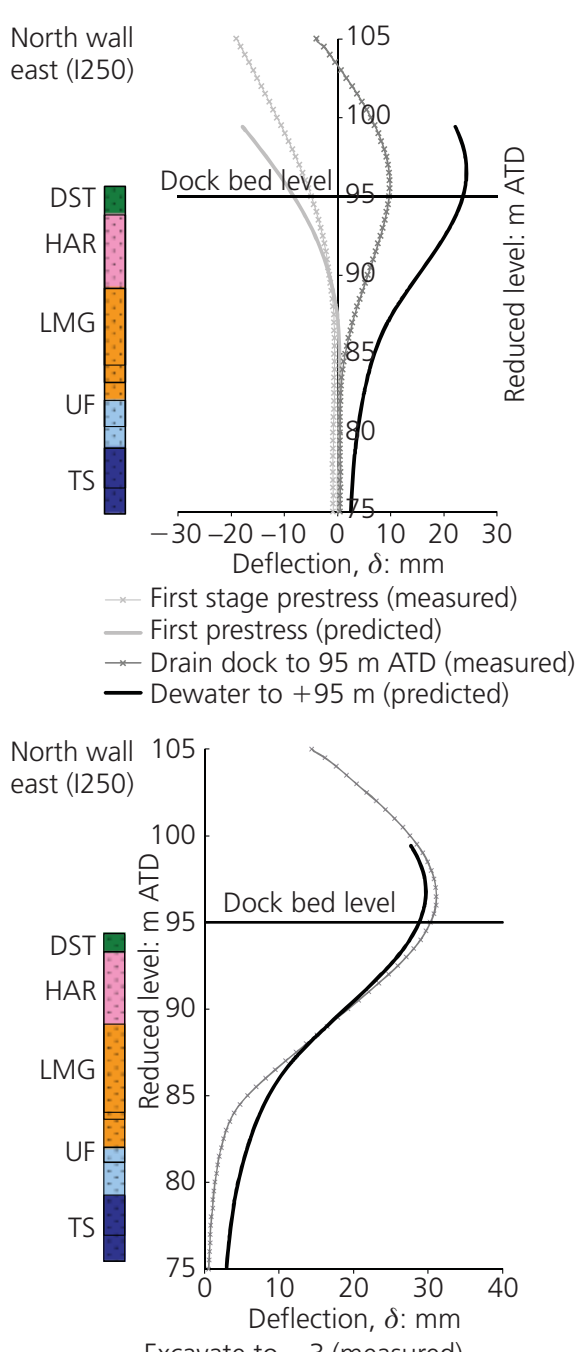

$\rightarrow$ Excavate to -3 (measured)

- Excavate to -3 (predicted)

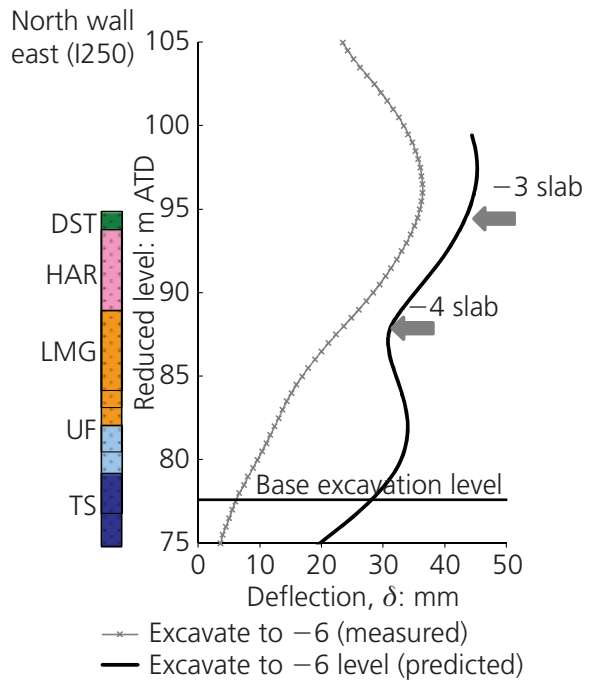

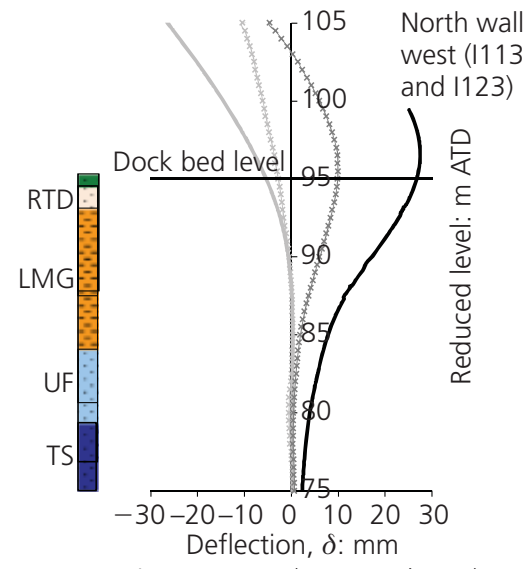

* First prestress (measured I113)

— First prestress (predicted)

* Drain dock to 95 m ATD (measured I113)

(a)

- Dewater to +95m (predicted)

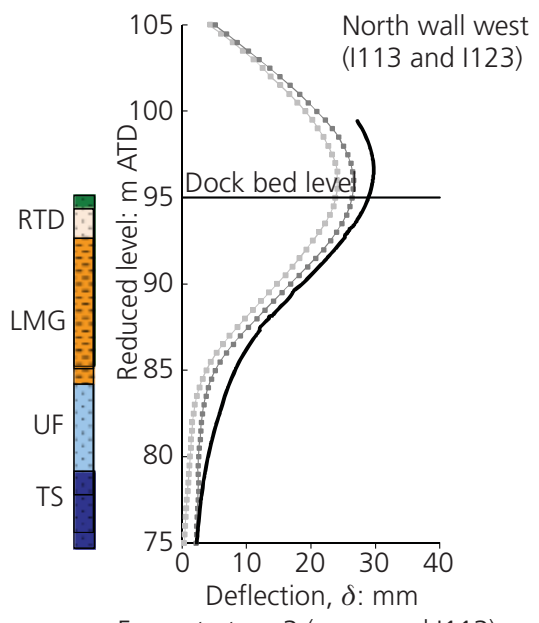

- Excavate to -3 (measured I113)

- Excavate to -3 (predicted)

(b) - Excavate to -3 (measured 1123)

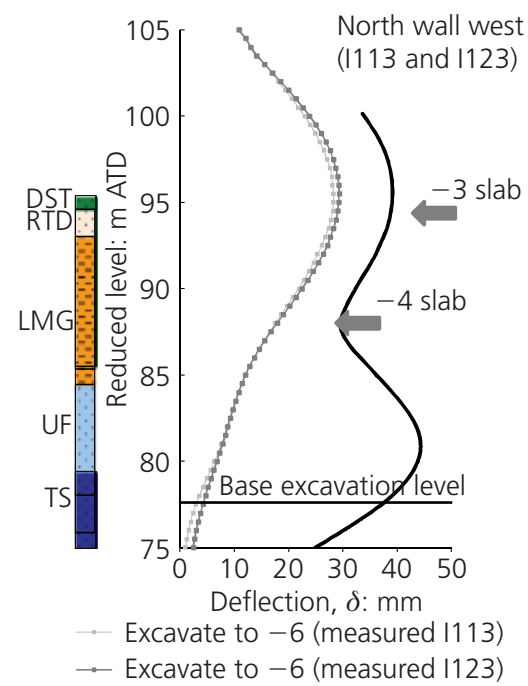

(c) - Excavate to -6 level (predicted)

Figure 10. Comparison of predicted and measured wall deflection at north wall west and east: (a) prestress and drain dock; (b) excavate to -3 level; (c) excavate to -6 level 
Interestingly, the rate of change of deflection over time also increased due to piling activities. The closest line of piles was $10 \mathrm{~m}$ from the retaining wall. This resulted in between 2 and $4 \mathrm{~mm}$ of additional movement and was possibly attributable to stress relief during boring. Another reason could be sand bands within the clays partially draining into the dry pile bore. This was consistent with drops in pore pressure measured in the piezometers; this was more pronounced towards the centre and west sections of the wall than shown in the data presented in Figure 11.

Taking out the effects of construction activities, the movement due to this partial consolidation typically varied between 2 and $6 \mathrm{~mm}$, with less movement at inclinometer I272 (shown in plan on Figure 2) close to the corner. The maximum lateral deflection of the wall associated with these effects varies at a rate of between 0.5 and $1 \mathrm{~mm} / \mathrm{month}$ along the whole north wall. The maximum value occurred at the west of the site where the clays are thicker and closer to the dock bed level. Prior to the start of excavation to the -3 level, the north wall east moved between 17 and $23 \mathrm{~mm}$.

\subsection{Excavation to -3 slab level}

Following completion of the piling (secant wall, tension and plunge column piles) from dock bed level, excavation commenced for the construction of the -3 level slab and this was typically to a depth of around $2 \mathrm{~m}$ below the existing dock bed level. The maximum measured wall movement for the north wall, at the end of excavation to the -3 level slab, was between 26 and
$30 \mathrm{~mm}$ (at $\approx 95 \mathrm{~m}$ ATD). This compared to predicted values of around $30 \mathrm{~mm}$, see Figure 10(b). This confirmed that in general the $\delta_{\text {amber }}=80 \% \quad \delta_{\text {red stage, }}$, discounting the effects of UXO drilling in the dock for the early dig stages.

Once this slab was cast, construction of the station box continued using the top-down techniques through openings in this slab. A slab at level -4 was then constructed, but is not discussed further here.

\subsection{Excavation to -6 slab level}

The excavation to the base slab was completed in July 2011. The recorded wall deflections prior to casting of the base slab are shown in Figure 10(c). The cofferdam performed better than expected within the Lambeth Group sands and Thanet Sand (i.e. below $82 \mathrm{~m}$ ATD). The expected rotation of the wall was not seen at the -4 slab level and this suggests that the Thanet Sand Formation has a larger strength and stiffness. Further back analysis of the retaining structure is likely to lead to enhanced design parameters in this stratum.

In summary, the measured deflections recorded at the end for stage 'excavation to -6 ' were 29 and $36 \mathrm{~mm}$ for the north wall west and east respectively. This equates to a $\delta / H$ ratio of between 0.11 and $0 \cdot 14 \%$ respectively, assuming a retained height $(H)$ as depth below dock water of $26 \mathrm{~m}$. This compares favourably with other top-down construction case histories for a high-stiffness support system, as shown in figure A2.1, in Ciria C580 (Gaba et al., 2003).

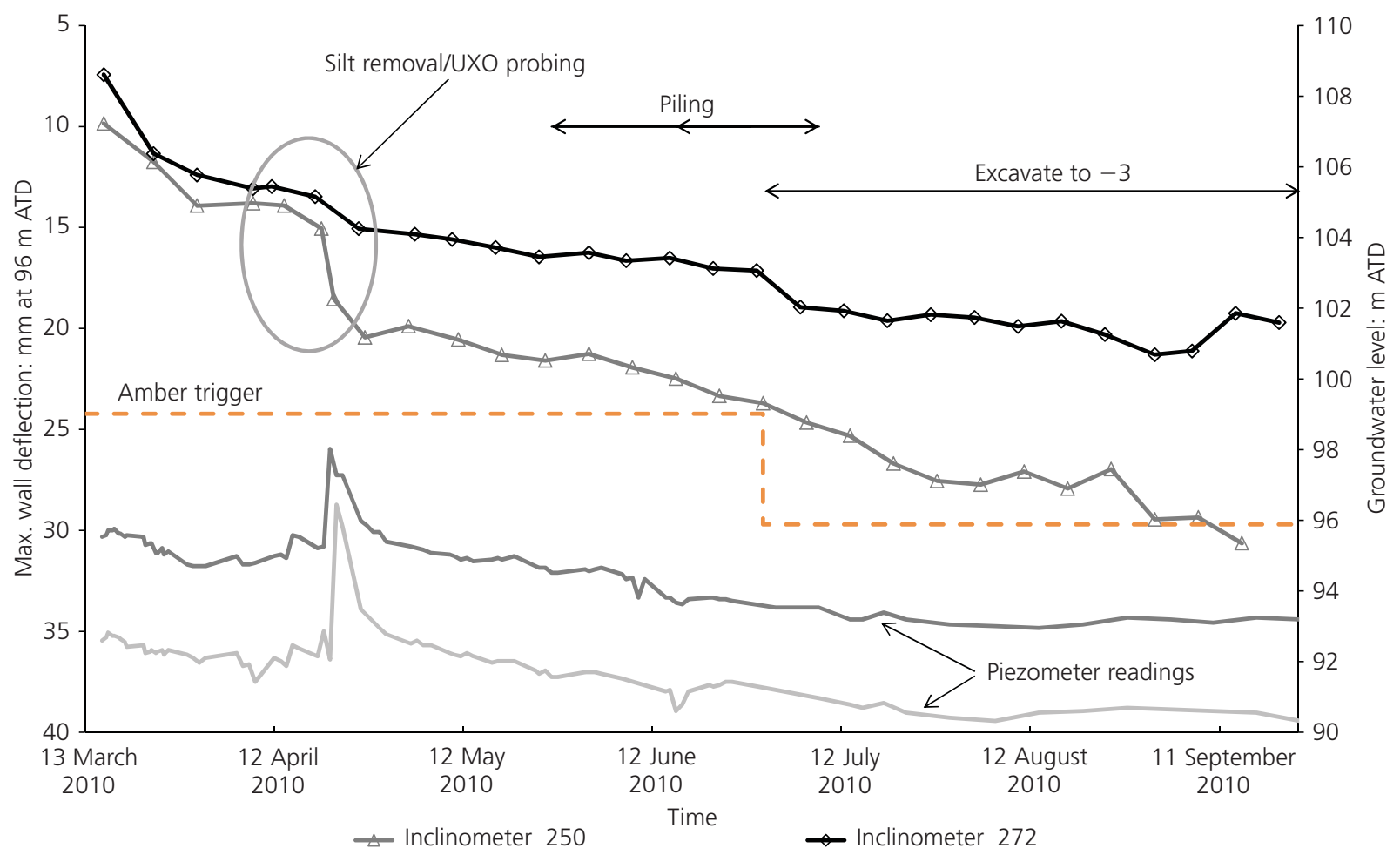

Figure 11. Measured maximum lateral deflection and piezometer readings (north wall east) 


\section{Conclusion}

The key challenge facing the project team was to design and construct a single skin cofferdam to retain $9 \mathrm{~m}$ of dock water and to accommodate 'sway' effects due to asymmetric loading.

The tie-backed retaining wall system proved a successful method of constructing deep excavations in a dock environment, with the major advantage of having no temporary props obstructing the work site, thus allowing restriction-free piling from dock bed level. The Giken piling system successfully installed all tubular piles over water to the design depth, which allowed extension of the retaining wall using conventional reinforced concrete piles into deeper strata for the construction of the station box, the first such project over water of this kind in the UK. This had advantages over traditional driven techniques in reducing the noise impact on adjacent commercial buildings and resulted in significant savings in both time and cost. This paper provides useful guidance to practising engineers on the design and construction for future cofferdams using this system.

Lower aquifer dewatering was extended for the first time to around $3 \mathrm{~m}$ above the top of the Chalk, drawing on previous experience of dewatering the upper Thanet Sand; this proved challenging. This was to a level below all anchors and wall piles. Bored pile construction was thereby allowed to proceed without the need for drilling support fluid and resulted in significant improvement in pile production.

Key to the success of the project was a comprehensive monitoring system installed in advance of the works, which allowed adequate baseline measurements to be taken, changes to be made to both the trigger values and design optimisation during construction, resulting in the removal of temporary props at the station ends.

Large underwater berm construction using excavated Thanet Sand was successfully completed following non-standard laboratory trials. Careful consideration of the method of fill placement is needed to optimise berm geometry. This reduced the volume of station spoil being sent to landfill.

Consolidation/creep effects in the clay resulted in between $0 \cdot 5$ and $1 \mathrm{~mm}$ of wall deflection per month being observed. It is recommended that the effects of construction time are considered as part of any wall design in Lambeth Group clay. Consideration should also be given to any construction activities that are planned in front of a retaining structure to ensure that the design is robust and that careful control is exercised on site.

In general, reasonable agreement with the measured deflections of the Giken wall was obtained for the early excavation stages. The exception was at the north wall east where the effects of drilling for UXO caused the wall to move more than anticipated in the design. In general, it was shown that most probable deflections were around $80 \%$ of design predictions and this provides a useful rule of thumb for calculating amber trigger values for the early dig stages and for similar future projects. $\delta / H$ ratio was between $0 \cdot 11$ and $0 \cdot 14 \%$ for a retained height of $26 \mathrm{~m}$, which compares well to published case histories.

A back analysis is planned and it is expected that the stiffness and strength of the Thanet sands are likely to lead to improved design parameters.

\section{Acknowledgements}

The authors would like to thank John Crack and Cliff Bryant from Canary Wharf Contractors Ltd for their kind permission to publish the data presented. The authors would also like to thank their colleagues at Ove Arup and Partners Ltd for their contribution both during the project and in compiling this paper; in particular, Chris Barker, for reviewing the final draft.

\section{REFERENCES}

Gaba AR, Simpson B, Powrie W and Beadman DR (2003) Embedded Retaining Walls Guidance for Economic Design. Construction Industry Research and Information Association (Ciria), London, UK, Ciria C580.

Highways Agency (2000) The Highways Agency Manual of Contract Documents for Road Works. Highways Agency, UK, Specification for Highway Works, vol. 1.

Newman RL, Chapman TFP and Simpson B (1991) Evaluation of pile behaviour from pressuremeter tests. Proceedings of the 10th European Conference on Soil Mechanics and Foundations, Florence, Italy. AA Balkema, Rotterdam, the Netherlands, pp. 501-504.

Simpson B, Blower T, Craig RN and Wilkinson WB (1989) The engineering implications of rising groundwater levels in the deep aquifer beneath London. Construction Industry Research and Information Association (Ciria), London, UK, Ciria Special publication 69.

Yeow HC, Nicholson D, Bryant C and Westbury M (2012) Achieving more for less at Canary Wharf Crossrail Station, London. Proceedings of the Institution of Civil Engineers Civil Engineering 165(5): 50-57.

\section{WHAT DO YOU THINK?}

To discuss this paper, please email up to 500 words to the editor at journals@ice.org.uk. Your contribution will be forwarded to the author(s) for a reply and, if considered appropriate by the editorial panel, will be published as a discussion in a future issue of the journal.

Proceedings journals rely entirely on contributions sent in by civil engineering professionals, academics and students. Papers should be 2000-5000 words long (briefing papers should be 1000-2000 words long), with adequate illustrations and references. You can submit your paper online via www.icevirtuallibrary.com/content/journals, where you will also find detailed author guidelines. 